УДК 338.432;631.1

DOI: $10.15673 /$ fie.v12i4.1918

\author{
Ринкова А.А. \\ аспірант \\ кафедра менеджменту і логістики \\ Одеська національна академія харчових технологій \\ вул. Канатна 112, м. Одеса, Україна, 65039 \\ E-mail: arynkova96@gmail.com \\ ORCID ID: 0000-0001-7794-7225
}

\title{
ОРГАНІЧНИЙ СЕКТОР ЕКОНОМІКИ В УКРАЇНІ ТА СВІТІ
}

У статті розглянуто переваги органічного виробництва в економічному, екологічному та соціальних аспектах. Представлено аналіз кількості українських виробників-операторів за період 2016-2019 роки, статистичні дані з експорту, світовий і європейський рейтинги по площі земель зайнятих під органіку. Вивчено органічне виробництво у світі, виділено основні напрями його розвитку, стандартизацію продукції. Аналізуючи цей досвід та всі тенденції та перспективи органічного виробництва в Україні, запропоновано певні інструменти його стимулювання, зокрема удосконалення правового регулювання, пільгове кредитування й оподаткування, бюджетні виплати, державну підтримку НДДКР, створення центрів контролю якості, сертифікацію та страхування. Практична значимість дослідження обумовлена тим, що впровадження представлених інструментів стимулювання розвитку органічного виробництва забезпечить збільшення попиту на органічну продукцію, підвищення конкурентоспроможності на міжнародних ринках, поліпшення екологічного стану в країні.

Ключові слова: органічне виробництво, виробники-оператори, органічна продукція, стандартизація, органіка, фермери.

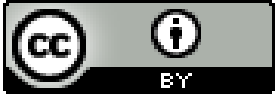

This work is licensed under a Creative Commons Attribution 4.0 International License http://creativecommons.org/licenses/by/4.0/
Постановка проблеми та зв'язок 3 важливими науковими та практичними завданнями. Питання розвитку органічного сектору економіки України є досить актуальним, що пов'язане насамперед з екологічною безпекою, оздоровленням нації, а отже підвищенням рівня життя українського народу та вступом до СОТ і євроінтеграцією.

Даний напрям господарської діяльності є досить ефективним в багатьох сферах, тому повинен стати пріоритетним для держави та аграрних підприємств. Органічне виробництво дає змогу активувати молодь до роботи на селі, привабити іноземних інвесторів, підвищити конкурентоспроможність на національному та міжнародному ринках та активізувати агробізнес в цілому.

Аналіз останніх публікацій по проблемі. У своїх працях звертали увагу на різні аспекти органічного виробництва такі науковці, як: В.І. Артиша, А.В. Вдовиченко, О.М. Довгань, Т.О. Зайчук, Н.В. Зіновчук, Є.В. Милованова, В.М. Писаренка, О.В. Ковальової, О.І. Корніцької, О.І. Шкуратова, В.А. Чудовської та інших.

Формулювання цілей дослідження. Метою дослідження $\epsilon$ аналіз сучасного стану органічного виробництва в Україні та світі, визначення переваг та недоліків цієї сфери економіки, пропозиції щодо покращення умов ії розвитку.

Для досягнення поставленої мети необхідно вирішити наступні завдання:
- виявити головні переваги та особливості органічного виробництва;

- проаналізувати тенденції розвитку органічної продукції в Україні;

- визначити головні принципи успішності країн-лідерів в розвитку цього сектору;

- запропонувати можливі заходи та інструменти стимулювання розвитку органічного виробництва в Україні.

Виклад основних результатів та його обгрунтування. Закон України «Про виробництво та обіг органічної сільськогосподарської продукції та сировини» визначає виробництво органічної продукції як виробничу діяльність фізичних або юридичних осіб, де під час такого виробництва виключається застосування хімічних добрив, пестицидів, генетично модифікованих організмів (ГМО), консервантів, та на всіх етапах виробництва (вирощування, переробки) застосовуються методи, принципи та правила, визначені цим Законом для отримання натуральної (екологічно-чистої) продукції, а також збереження та відновлення природних ресурсів [1].

Сучасний стан економіки України визначає певні орієнтири, пов'язані насамперед 3 продовольчою безпекою держави, оздоровленням населення та покращенням екологічного стану країни. 3 огляду на це, органічне виробництво постає пріоритетним напрямком розвитку сільськогосподарського сектору економіки (рис. 1) [5]. 


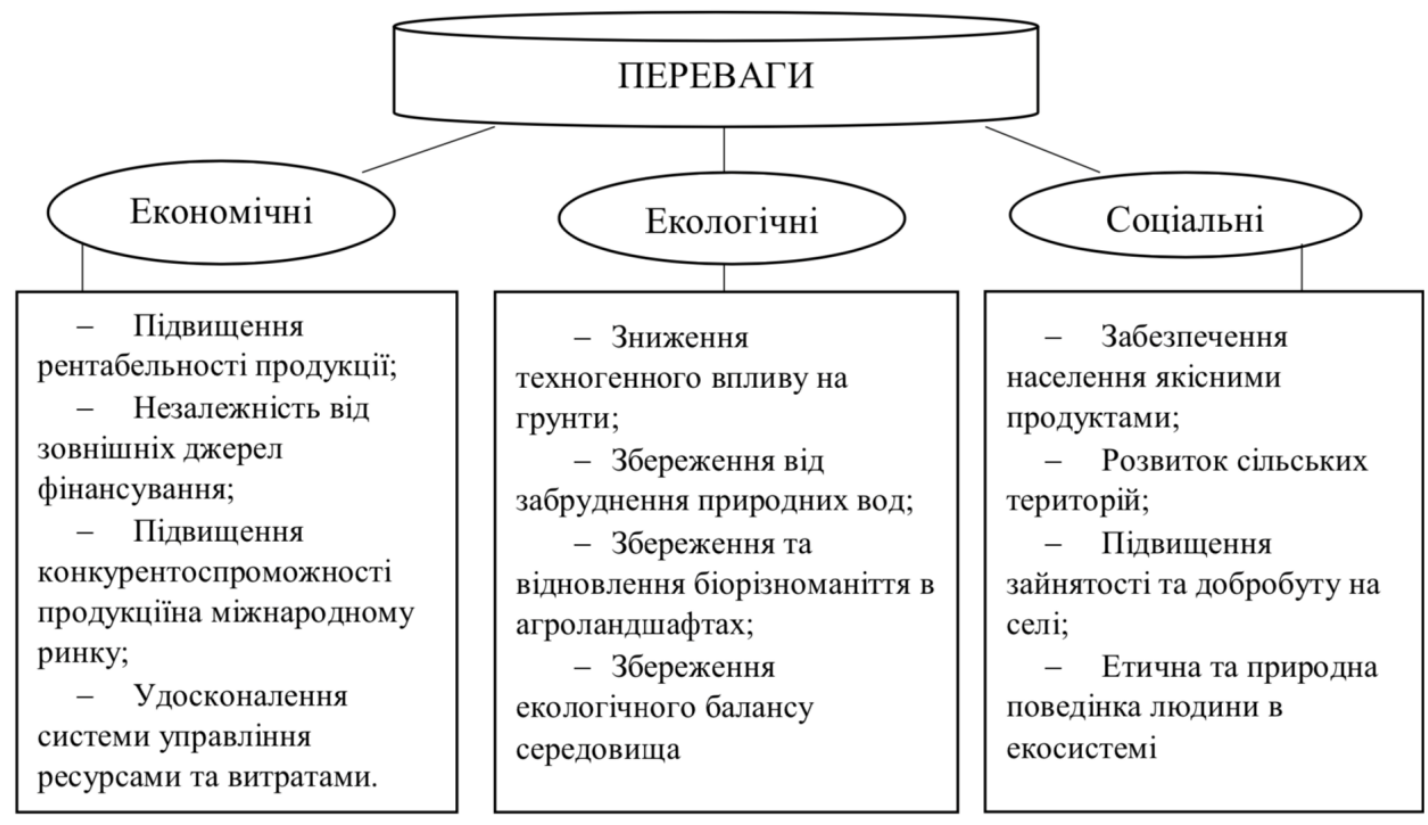

Рис. 1. Переваги органічного виробництва*

*Складений автором за даними джерела [2]

Недосконалість законодавства негативним чином позначається на функціонуванні вітчизняного органічного ринку, іміджі країни в рамках COT, як наслідок перешкоджає розвитку виробників націлених на експорт продукції.

Попри всі недоліки, в Україні працює близько 450 органічних сільськогосподарських виробників (рис. 2). У 2019 році наша країна зайняла 20 місце у світі та 11 в Свропі по площі земель зайнятих під органічне виробництво[2,4].

Продукція експортується в понад 45 країн світу, до яких відносяться: Нідерланди, Німеччина, Італія, Австрія, Польща, Швейцарія, Болгарія, Угорщина та ін. Основними лініями експорту органічних товарів виступають: зернові, бобові, олійні, ягоді, фрукти [3].

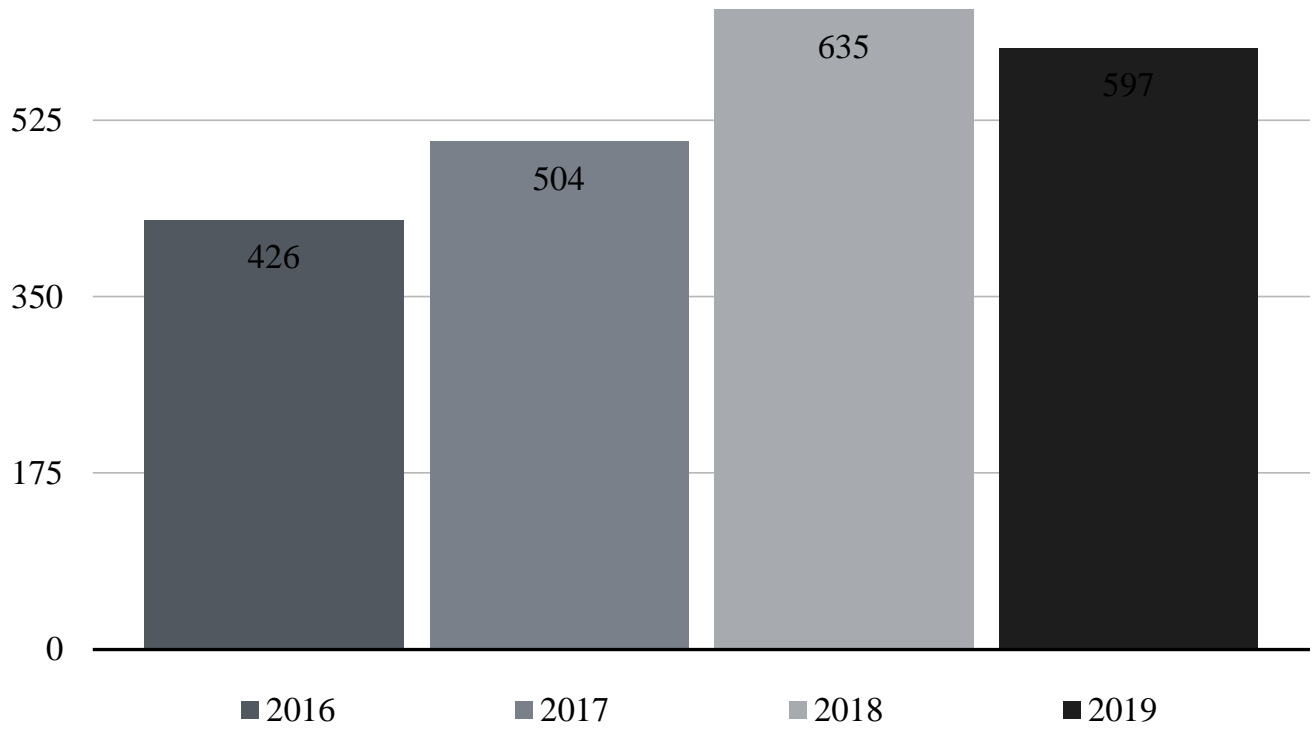

Рис. 2. Кількість виробників - операторів в Україні* *складено автором за даними джерела [3] 
Що стосується органічного виробництва у світі, лідерами впродовж багатьох років залишаються Австралія, Аргентина, Китай та Бразилія [11].

В Свропі знаходиться $24 \%$ органічних світових земель, де понад 10\% припадає під виробництво в Ліхтенштейні (30\%), Австрії (16\%), Швейцарії $(11,1 \%)$ та Швеції $(10,8 \%)$. В Україні натомість цей відсоток складає менш як 1\%. [9].

В США органічна продукція реалізується одразу на місцевих фермерських ринках. В Свропейських країнах понад 70\% органіки реалізується у роздрібній торгівлі. Крім того, популярності набувають «органічні ресторани», поширене також органічне дитяче харчування [7,9].

Відповідно до міжнародних стандартів, виділяють три головні напрямки розвитку в області органічного сектору, перевагою яких є державна підтримка, інвестиції чи соціальні можливості. Так, виділяють:

1. Великотоварне виробництво органічної продукції, в яке постачається багато інвестицій.

2. Середньотоварне виробництво органіки, куди виділяють понад 50\% збоку державної підтримки.

3. Дрібнотоварне виробництво, 3 ознакою соціального внеску, а саме: збільшення кількості робочих місць на селі [8].

Світовий досвід свідчить про те, що найголовнішою підтримкою розвитку органічного виробництва постають: державна підтримка, інвестиції з боку підприємств та прозора система стандартизації, сертифікації, маркування та прозорої системи контролю за якістю продукції [10].
Аналізуючи світовий досвід та сучасний стан органічного виробництва в Україні, можна виділити наступні проблеми, боротьба з якими дасть поштовх в розвитку цього сектору:

- відсутня законодавча та нормативноправова база для органічної продукції;

- складна та довготривала сертифікація;

- відсутність чітко визначеної державної стратегії, а отже і державної підтримки аграріїв;

- контроль збоку держави, за виконання роботи фермерів та підприємств 3 вирощування та просування органічної продукції в рамках стандартів, не виконується належним чином, а отже акредитування на міжнародному рівні неможливе;

- низький рівень обізнаності та умінь щодо органічного землеробства та його сертифікації;

- відсутність знань в області біотехнологічної боротьби зі шкідниками, тощо.

Попри всі зрушення в цій сфері, потрібно зазначити, що ринок органічної продукції розвивається дуже повільно. Найголовнішим фактором, що стримує його розвиток $є$ висока ціна в порівнянні 3 неорганічними аналогами. Проте, європейські стандарти більш лояльно ставляться до ціноутворення, виставляючи націнку в розмірі 20-30\%, натомість вітчизняні виробники встановлюють ціни на 50, а деколи і 300\% дорожче ніж аналоги[6,8].

Аналізуючи всі тенденції, пропонуємо наступну розробку механізму стимулювання розвитку органічного виробництва на підприємствах аграрного сектору (рис. 3).

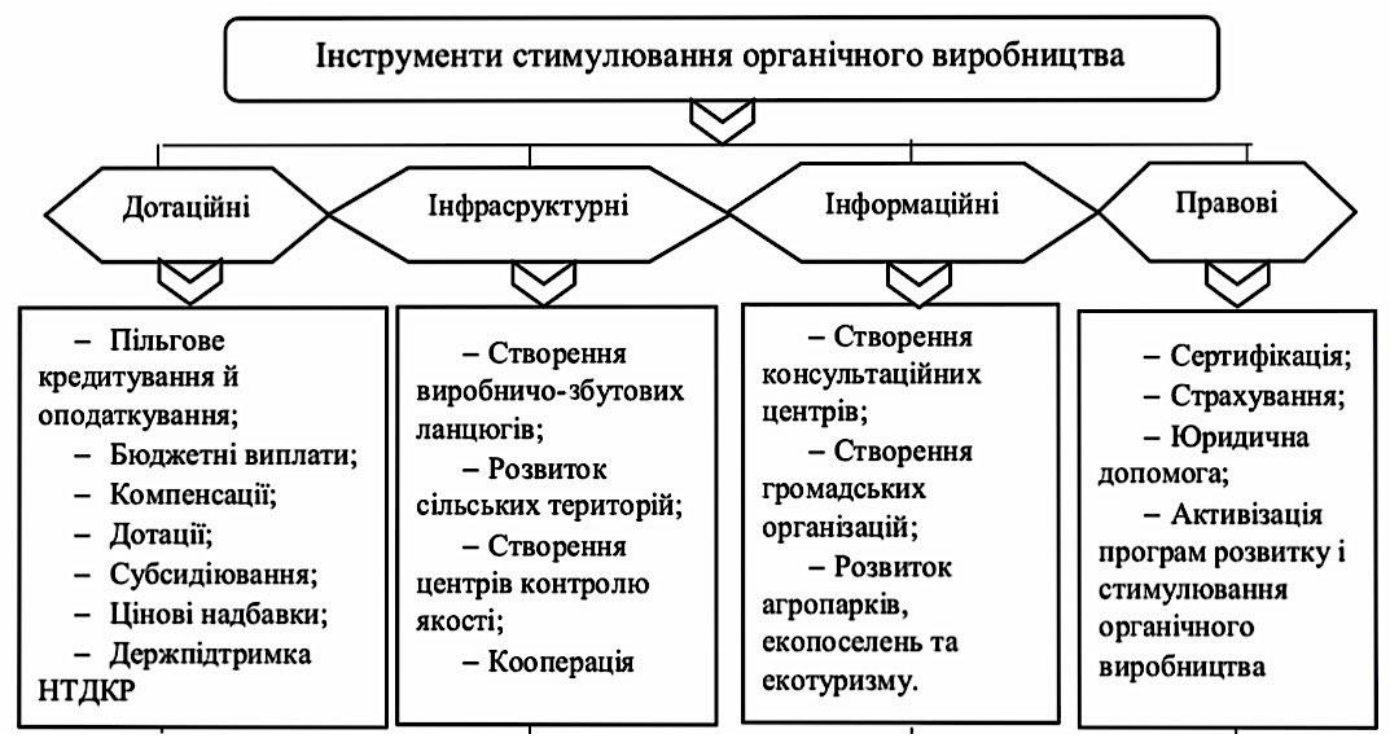

Рис. 3. Інструменти стимулювання органічного виробництва* *складено автором

Висновки та перспективи подальших досліджень. Даний напрям господарської діяльності $€$ достатньо ефективним в багатьох сферах, тому повинен стати пріоритетним для держави та аграрних підприємств. Органічне виробництво дає змогу активу- вати молодь до роботи на селі, привабити іноземних інвесторів, підвищити конкурентоспроможність на національному та міжнародному ринках та активізувати агробізнес в цілому.

Недосконалість законодавства у цій сфері 
негативним чином позначається на функціонуванні вітчизняного органічного ринку, іміджі країни на ринку “органіки” в рамках СОТ, як наслідок перешкоджає розвитку виробників націлених на експортерів.

Попри всі недоліки цього сектору, в Україні спостерігається динаміка зростання загальної площі земель під органіку. Імпортується біль ніж 80 видів органічних товарів у 35 країн світу.

Аналізуючи досвід виробництва органіки у світі, було визначено головних лідерів цього сектору - Австралія, Аргентина, Китай та Бразилія. Цю позицію вони займають через високий рівень земель, які використовуються саме під органічну продукцію. Окрім того, все виробництво проходить за певними міжнародними стандартами, а продукція першочергово реалізується в межах своєї країни. Популярності також набувають «органічні ресторани», поширене також органічне дитяче харчування.

Світовий досвід свідчить про те, що найголовнішою підтримкою розвитку органічного виробництва постають: державна підтримка, інвестиції з боку підприємств та прозора система стандартизації, сер- тифікації, маркування та прозорої системи контролю за якістю продукції.

На основі світового досвіду та зазначених проблем в органічному секторі України, першочерговим завданням для розвитку цього сектору пропонуємо удосконалити правове регулювання органічного виробництва, обігу та маркування органічної продукції, створити систему контролю за виробництвом на ринку, все це допоможе запобігти фальсифікованої органічної продукції та відновлення підтримки збоку держави у вигляді пільгового кредитування, дотацій, оподаткування та інше.

Таким чином, перспективи подальших досліджень в органічному секторі економіки необхідні для розвитку сільського господарства, а впровадження результатів дослідження допоможе забезпечити збільшення попиту на органічну продукцію, підвищення конкурентоспроможності на міжнародних ринках, поліпшення екологічного стану в країні, а так само залучення нових фермерів-виробників в даний сектор економіки.

\section{Література}

1. Про органічне виробництво та обіг органічної сільськогосподарської продукції та сировини: Закон України за станом на 12.02.2015. URL: http://zakon5.rada.gov.ua/laws/show/425-18 (дата звернення: 25.09.2020)

2. Артиш В.І. Особливості органічного агровиробництва в концепції сталого розвитку АПК України // Економіка АПК. 2017. №4 С. 9-23

3. Внутрішній ринок органічної продукції України, експорт та імпорт: веб-сайт. URL: https://agropolit.com/infographics/view/95 (дата звернення: 03.10.2020)

4. Томашевська О. А. Виробництво органічних продуктів в Україні // Агросвіт, 2012. №21 С. 2-5.

5. Органічне виробництво в Україні / Міністерство агроекономіки: веб-сайт. URL: http://minagro.gov.ua/node/23346. (дата звернення: 03.10.2020)

6. Розвиток органічного ринку в світі: веб-сайт. URL: http://organic.uа (дата звернення:15.10.2020)

7. Томашевська О.А. Органічне виробництво в світі // Економіка природокористування та екологізація навколишнього середовища. 2016. №44. С.161-163.

8. Agence Bio: La Bio dans le monde. Agence Bio Montreuil. URL: https://www.agencebio.org/wp- content/uploads/2018/10carnet_monde_2017.pdf (viewed on: 12.10.2020).

9. David Dumaresq. Organic Agriculture in Australia. URL:

https://www.researchgate.net/publication/242589047_Organic_Agriculture_in_Australia (viewed on: 02.10.2020).

10. Louise Luttikholt, Executive Director, IFOAM - Organics International, 53113 Bonn, Germany. URL: www.ifoam.bio (viewed on: 02.10.2020).

11. Organic Farming Provides Reliable Environmental Benefits but Increases Variability in Crop Yields: A Global Meta-Analysis. Front. Sustain. Food Syst., 27 September. 2019. URL: https://www.frontiersin.org/articles/10.3389/fsufs.2019.00082/full (viewed on: 9.10.2020). doi: $10.3389 /$ fsufs. 2019.00082

\section{ОРГАНИЧЕСКИЙ СЕКТОР ЭКОНОМИКИ В УКРАИНЕ И МИРЕ}

В статье рассмотрены преимущества органического производства в экономическом, экологическом и социальных аспектах. Представлен анализ количества украинских производителей- 
операторов за период 2016-2019 годы, статистические данные по экспорту, мировой и европейский рейтинги по площади земель занятых под органику. Изучено органическое производство в мире, выделены основные направления его развития, приоритеты и проблемные стороны. Анализируя опыт и все тенденции органического производства в Украине, предложено определенные инструменты его стимулирования, в частности: усовершенствование правового регулирования, льготное кредитование и налогообложение, бюджетные выплаты, государственную поддержку НИОКР, создание центров контроля качества, сертификации и страховании производства и продукции. Внедрение результатов исследования сделает органический сектор более привлекательным для фермеров, продукцию конкурентоспособной на международном уровне и обеспечит улучшение экологического состояния. Целью исследования является анализ современного состояния органического производства в Украине и мире, определение преимуществ и недостатков этой сферы экономики, предложения по улучшению условий ее развития. В результате исследования международной ситуации в органическом производстве, мы получили определенные принципы и знания, которые модем перенять для улучшения ситуации в секторе органики.

Практическая значимость исследования обусловлена тем, что внедрение представленных инструментов стимулирования развития органического производства обеспечит увеличение спроса на органическую продукцию, повышение конкурентоспособности на международных рынках, улучшение экологического состояния в стране, а так же привлечение новых фермеров-производителей в данный сектор экономики.

Ключевые слова: органическое производство, производители-операторы, органическая продукция, фермеры, органика.

Rynkova A.

Postgraduate

Department of Management and Logistics

Odessa National Academy of Food Technologies

Kanatna str., 112 Odesa, Ukraine, 65039

E-mail: arynkova96@gmail.com

ORCID ID: 0000-0001-7794-7225

\section{ORGANIC SECTOR OF ECONOMY IN UKRAINE AND WORLD}

The article discusses the benefits of organic production in economic, environmental and social aspects. An analysis of the number of Ukrainian manufacturers-operators for the period 2016-2019, statistical data on exports, world and European rankings by the area of land occupied by organic matter have been presented. Organic production in the world has been studied, the main directions of its development, priorities and problematic aspects have been identified. Analyzing the experience and all the trends of organic production in Ukraine, certain tools have been proposed to stimulate it, in particular: improvement of legal regulation, preferential lending and taxation, budget payments, government support for R\&D, the creation of quality control centers, certification and insurance of production and products. The implementation of the research results will make the organic sector more attractive to farmers, products competitive at the international level and will provide an improvement in the ecological state. The aim of the study is to analyze the current state of organic production in Ukraine and the world, to identify the advantages and disadvantages of this sector of the economy, proposals for improving the conditions for its development. As a result of the study of the international situation in organic production, we received certain principles and knowledge that we can adopt to improve the situation in the organic sector.

The practical significance of the study is due to the fact that the introduction of the presented tools to stimulate the development of organic production will increase the demand for organic products, increase competitiveness in international markets, improve the environmental situation in the country, as well as attract new farmers-producers to this sector of the economy.

Key words: organic production, producers-operators, organic products, farmers, organic.

\section{References}

1. Pro orhanichne vyrobnytstvo ta obih orhanichnoï silskohospodarskoï produktsiï ta syrovyny: Zakon Ukrainy za stanom na 12.02.2015. (2015). Retrieved September 25, 2020, from http://zakon5.rada.gov.ua/laws/show/425-18

2. Artysh, V. I. (2017). Osoblyvosti orhanichnoho ahrovyrobnytstva v kontseptsiï staloho rozvytku APK Ukraïny. Ekonomika APK, (4), 9-23.

3. Vnutrishnii rynok orhanichnoi produktsii Ukrainy, eksport ta import. Retrieved October 03, 2020, from https://agropolit.com/infographics/view/95 
4. Tomashevska, O. A. (2012). Vyrobnytstvo orhanichnykh produktiv v Ukraïni. Ahrosvit, (21), 2-5.

5. Orhanichne vyrobnytstvo v Ukrä̈ni. Ministerstvo ahroekonomiky. Retrieved October 03, 2020, from http://minagro.gov.ua/node/23346

6. Rozvytok orhanichnoho rynku v sviti. Retrieved October 15, 2020, from http://organic.ua

7. Tomashevska, O. A. (2016). Orhanichne vyrobnytstvo v sviti. Ekonomika pryrodokorystuvannia ta ekolohizatsiia navkolyshnoho seredovyshcha, (44), 161-163.

8. Agence Bio: La Bio dans le monde. Agence Bio Montreuil. Retrieved October 12, 2020, from https://www.agencebio.org/wp- content/uploads/2018/10carnet_monde_2017.pdf

9. David Dumaresq. Organic Agriculture in Australia. Retrieved October 02, 2020, from https://www.researchgate.net/publication/242589047_Organic_Agriculture_in_Australia

10. Luttikholt, L. Executive Director, IFOAM - Organics International. Retrieved October 02, 2020, from www.ifoam.bio

11. Organic Farming Provides Reliable Environmental Benefits but Increases Variability in Crop Yields: A Global $\begin{array}{llllll}\text { Meta-Analysis. } & \text { (2019). } & \text { Retrieved } & \text { October } & 09, & 2020,\end{array}$ https://www.frontiersin.org/articles/10.3389/fsufs.2019.00082/full doi: 10.3389/fsufs.2019.00082

Received 21 October 2020

Approved 4 November 2020 Available in Internet 29.12.2020

Цитування згідно ДСТУ 8302:2015

Ринкова А.А. Органічний сектор економіки в Україні та світі // Економіка харчової промисловості. 2020. Т.12, вип. 4. С. 92-97. doi: 10.15673/fie.v12i4.1918

Cite as APA style citation

Rynkova, A. (2020). Organic sector of economy in Ukraine and world. Food Industry Economics, 12(4), 92-97. doi: 10.15673/fie.v12i4.1918 